УКРАЇНСЬКИЙ АНТАРКТИЧНИЙ ЖУРНАЛ

УАЖ № 9, 202-205 (2010)

УДК 577.112.37:115.083:57.045

\title{
PIGMENT-PROTEIN COMPLEXES OF THYLAKOID MEMBRANES OF DESCHAMPSIA ANTARCTICA DESV. PLANTS
}

\author{
Taran N.Yu. ${ }^{1}$, Ozheredova I.P. ${ }^{1}$, Storozhenko V.O. ${ }^{1}$, Svetlova N.B. ${ }^{1}$, Topchiy N.M. ${ }^{2}$ \\ ${ }^{1}$ Taras Shevchenko National University of Kyiv, Volodymyrska str,. 64, Kyiv, Ukraine, 01033 \\ tarantul@univ.kiev.ua \\ ${ }^{2}$ M.G. Kholodny Institute of Botany of the National Academy of Sciences of Ukraine, Tereshchenkivska \\ str., 2, Kyiv, Ukraine, 01601 \\ membrana@ukr.net
}

\begin{abstract}
The molecular analysis results of pigment-protein complexes of photosynthetic membranes of Deschampsia antarctica plants, one of the native representatives of the Antarctic region are presented. Bioinformatics searching of genome products of Deschampsia antarctica in available protein databeses related to the structure and function of plastids was carried. The searching of Arabidopsis thaliana and Oryza sativa japonica homolog search submitted in free databases is also performed. The results of comparative analysis of primary sequences of the known and potential products are presented.
\end{abstract}

Key words: Deschampsia, pigment-protein complexes, proteome.

Реферат. Наведено результати молекулярного аналізу пігмент-білкових комплексів i розглянуто особливості ліпідного складу фотосинтетичних мембран Deschampsia antarctica одного з представників флори Антарктиди. Здійснено біоінформаційний пошук у доступних базах даних продуктів геному Deschampsia antarctica, які структурно та функціонально пов'язані з пластидами. Також здійснено пошук їх гомологів у протеомах Arabidopsis thaliana та Oryza sativa japonica. Наведено результати порівняльного аналізу первинних послідовностей потенційних та відомих продуктів.

Ключові слова: Deschampsia, пігмент-білкові комплекси, протеом.

Реферат. Приведены результаты молекулярного анализа пигмент-белковых комплексов и рассмотрены особенности липидного состава фотосинтетических мембран Deschampsia antarctica - одного из представителей флоры Антарктики. Осуществлен биоинформационный поиск в доступных базах данных продуктов генома Deschampsia antarctica, которые структурно и функционально связаны с пластидами. Также осуществлен поиск их гомологов в протеомах Arabidopsis thaliana и Oryza sativa japonica. Приведены результаты сравнительного анализа первичных последовательностей потенциальных и известных продуктов.

Ключевые слова: Deschampsia, пигмент-белковые комплексы, протеом.

\section{Introduction}

The investigations of protection responses of plants on abiotic stress conditions is actual today. Antarctic species Deschampsia antarctica Desv. (Poaceae) is unique plant object for studying of adaptive mechanisms of plants on abiotic stress action. This can be explained both the absence of breeding and biotechnological interferences in the development of this species and its unique habitat. 


\section{Taran N.Yu.: PIGMENT-PROTEIN COMPLEXES OF THYLAKOID MEMBRANES OF...}

Phenotypical and genotypic variability are the basis of plant adaptation on abiotic stress. Functioning of them provides the balance between the requirements of maximal ontogenetic adaptation and maintenance of phylogenetic flexibility of populations (Жученко, 1994; Кир'яченко, 2005).

Some abiotic factors in Antarctic are excessive illumination and elevated levels of UV-B radiation. Therefore formation of active paths of adaptation for maintenance of photosynthetic activity take place both at the level of the ultrastructural organization of organels (Gielwanowska, 2005), that provides effective mechanism of dissipation of excessive energy, and at a biochemical level of photosynthetic reactions.

Primary processes of photosynthesis take place in thylakoid membranes of chloroplasts during redox transformations of components of electron transport chain. They involved in adaptive transformations of photochemical processes. Thylakoid membranes contain five types of protein complexes, which realize distribution of a charge and transfer of electrons. There are photosystem I (PS I), photosystem II (PS II), their light-harvesting complexes, cytochrome $b_{\sigma} / f$ complexes of proton ATP-synthase $\left(\mathrm{CF}_{0}-\mathrm{CF}_{1}\right)$.

The aims of our investigation were isolation and analysis pigment-protein complexes of thylakoid membranes of chloroplasts and searching in accessible databases of amino acid sequences of $D$. antarctica which belong to pigment-protein complexes of thylakoid membranes and also carrying out of their comparative analysis with Arabidopsis thaliana (L.) and Oryza sativa L. ssp. japonica cv. Nipponbare sequences for finding-out of particularities of formation of adaptive reactions of $D$. antarctica plants at a level of primary processes of photosynthesis.

\section{Materials and methods}

The analysis of pigment-protein complexes of thylakoid membranes carried out by method of nondenaturing polyacrylamide gel electrophoresis in polyacrylamide gel with using of sodium lauryl sulfate (SLS) for decomposition of membranes desintegration (Anderson, 1980). The relative pigment-protein content was estimated by chlorophyll concentration that was determined in $80 \%$ acetone (Arnon, 1949). Electrophoregrams scaned ('Mustek', China) and then analyzed by TotalLab V1.10.

Searching of $D$. antarctica sequences was spent in open databases Swiss-prot / TREMBL (http://www.expasy.org). Searching of potential homologues was carried out by comparison of $D$. antarctica sequences with proteomes of $A$. thaliana and $O$. sativa, as vegetative organisms which are most full presented in databases. Searching of homologous sequences and determination of a homologous level carried out with BLASTp tool (http://www.ncbi.nlm.nih.gov/blast/Blast.cgi). The selection of homologous sequences for further analysis was spent by standard method according to which proteins is homologous under identity $\geq 25 \%$ with E-value $<10^{-3}$. Global equalization of protein sequences carried out with on-line resource Clustal with using of BLOSUM matrix. The analysis of domain architecture of amino acid sequences spent with on-line resource ART (http://smart.embl.de).

\section{Results and discussion}

We identified seven strips according to non-denaturing green SDS-electrophoresis. Each of them associated with pigment-protein complexes according to Anderson nomenclature (Anderson, 1980) (fig. 1).

In result of comparison of pigment-protein complexes of thylakoid membranes of $D$. antarctica plants with Pisum sativum L. plants (Топчій, 2006) the essential qualitative differences between them were not exposed. 
Taran N.Yu.: PIGMENT-PROTEIN COMPLEXES OF THYLAKOID MEMBRANES OF...

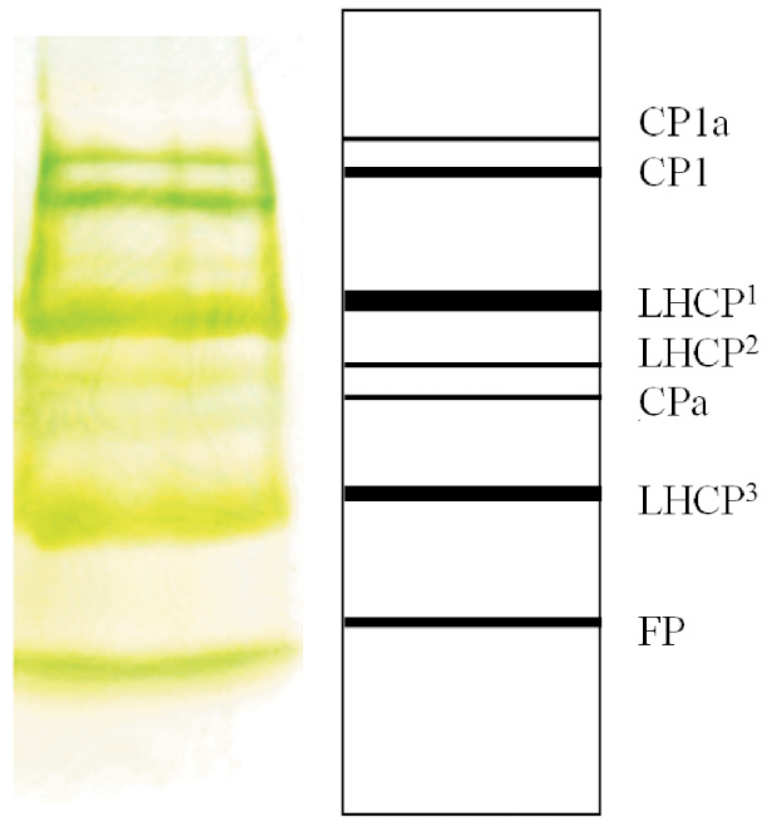

Fig. 1. Electrophoregram of pigment-protein complexes of thylakoid membranes. CP1a - complex of RC of PS I, which partially have own lightharvesting complex (LHC I); CP1 - complex of RC of PS I without LHC I; LHCP $^{1}$ oligomeric form of LHCII; LHCP ${ }^{2}$ - LHC I; $\mathrm{CPa}$ - the nearest to RC of PS II light-harvesting pigment-protein complex; $\mathrm{LHCP}^{3}$ - monomeric form of LHC II; FP - free chlorophyll

Quantitative differences in general content of LHCII (oligomerous (LHCP1) and monomerous (LHCP3) forms), chlorophyll content in $\mathrm{CPa}$, (protein complexes of complexes of near antenna) are revealed. In our opinion, quantitative differences associated with features of growth conditions of $D$. antarctica plants. Thus, the influences of excessive light and increased level of UV-B radiation.

The relative content of pigment-protein complexes of thylakoid membranes of D. antarctica plants is presented lower. CP1a and CP1 is 8,97 $\pm 0,38(\%)$ and 12,34 $\pm 0,26(\%)$, oligomerous form (LHCP1) of LHCII - 27,02 $\pm 0,53(\%)$, whereas monomeric form LHCP3) - 20,16 $\pm 0,61(\%)$. The relation between forms (LHCP 1/LHCP3) is equaled 1,34 $\pm 0,02$, general content of LHC II (LHCP $1+$ LHCP3) is $47,17 \pm 1,11(\%)$.

Scanning of databases has shown, that 37 amino acid sequences which belong to $D$. antarctica proteome currently there is in free access. From them 20 sequences are potential proteins or fragments of proteins with specified function and 17 are potential proteins or fragments of proteins which function is not determined. Thus, annotation of $D$. antarctica genome and proteome is on the initial stage of determination of function of all known proteins, and functions practically all known potential proteins are not determined finally.

In our work special attention pays to plastid proteins. We selected from databases 15 proteins, which had chloroplast origin and related to families RsbG and PsbC (Nixon, 1989, Luciski, 2006).

The comparison of Psb sequences of $D$. antarctica received from databases (ABS30954; ABS30955; ABS30956; ABS30957; ABS30958) demonstrated, that they are identical, and they are the sequencing of one potential product ('Clustal' program). The analysis of domain architecture of this fragment was conducted by online SMART recourse. It confirmed the accessory of this fragment to PsbC. The determination of fragment of protein domain architecture of Psb was impossible for $D$. antarctica plants. It associated with small sizes of amino-acid residues.

Searching of homological sequences in A.thaliana and O.sativa proteomes was lead (BLASTp instrument) for specification of function of $D$. antarctica hypothetical product. As result, have been allocated amino acid sequences NP051055 A.thaliana (identity of $97 \%$, E-value 0,00) and NP039367 O.sativa (identity of $98 \%$, E-value 0,00 ). In articles of databases they are presented proteins of PsbC 


\section{Taran N.Yu.: PIGMENT-PROTEIN COMPLEXES OF THYLAKOID MEMBRANES OF...}

family are a part and participate in binding of chlorophyll and $\beta$-carotene and transfer of excitation energy to reaction center (Barber, 2002).

Multiple global alignment of found sequences of $A$. thaliana and $O$. sativa with fragment has revealed the significant level of conservatism of this proteins (fig. 2).
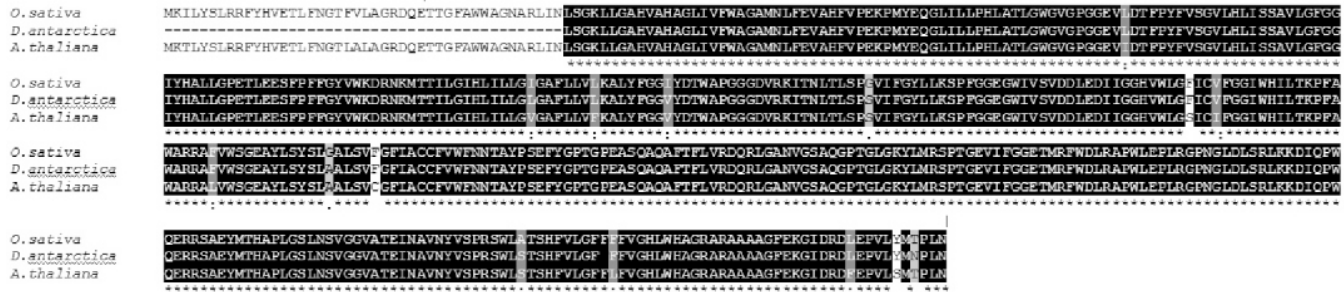

Fig. 2. Comparison of amino acid sequences of PS II protein fractions of D. antarctica, A. thaliana and O. sativa.

The structured area of these proteins includes from 31 to 473 amino-acid residues. The investigated fragment of $D$. antarctica sequence practically completely coincides with the sequence of proteins from 45 to 473

amino acid residue. But positions 106, 170, 177, 185, 245, 264, 427, 437, 463 had strong replacements, on 207, 277,470 positions was weak replacement, and on $242,282,468$ coincidence was absent. Probably strong replacements lead to the certain modifications in structure of this protein which provides the effective mechanism of excessive energy dissipation for maintenance photosynthesis in normal conditions.

\section{Conclusions}

Quantitative differences in general content of LHC II (oligomeric and monomeric forms), chlorophyll content in $\mathrm{CPa}$ zone (pigment-protein complexes of nearest antenna) are revealed. Results of global alignment and domain architecture have shown, that analyzed fragment of amino acid sequence of PS II protein fraction of $D$. antarctica has high affinity with sequences of $A$. thaliana and $O$. sativa which belong to PsbC family of proteins, and it is a fragment of a product of a gene of psbC family. Also it is possible to note, that in the given fragment is absent $\mathrm{C}$-final sequence, which have size as one or several exons.

\section{References}

Жученко А.А. Стратегия адаптивной интенсификации сельского хозяйства (концепция). - Пущино: ОНТИ ПНЦРАН. - 1994. - 148 с.

Кир'яченко С.С., Козерецька I.А., Ракуса-Сушевскі С. Deschampsia antarctica: генетичні та молекулярно-біологічні аспекти поширення в Антарктиці // Цитология и генетика. - 2005. - № 4. - С. $75-80$.

Топчій Н.М. Роль світлозбирального комплексу в адаптації вищих рослин до умов освітлення // Автореф. дис. к.б.н., біохімія. $-2006 .-21$ с.

Anderson J.M. P-700 content and polypeptide profile of chlorophyll-protein complexes of spinach and barley thylakoids // Biochim. Biophys. Acta. - 1980. - 591.-P. 113-126.

Arnon D.I. Cooper enzymes in isolated chloroplasts. Polyphenolase in Beta vulgaris // Plant Physiol. 1949. -24. - № 1. - P. 1-154.

Barber J. Photosystem II: a multisubunit membrane protein that oxidizes water // Curr. Opin. Struct. Biol. 2002.-12(4). - P. 523-530.

Gielwanowska I., Szczuka E. New ultrastructural features of organelles in leaf cells of Deschampsia antarctica Desv. // Polar Biol.-2005.-28.-P. 951-955.

Lucicski R., Jackowski G. The structure, functions and degradation of pigment-binding proteins of photosystem II // Acta biochim.pol. - 2006. - 53, № 4. P. 523-530.

Nixon P.J., Gounaris K, Coomber S.A. et al. psbC is not a photosystem two gene but may be an ndh gene. // J. Biol Chem. - 1989. - 264(24). - P. 14129-14135. 